Irena Sawicka ๑ https://orcid.org/0000-0003-1426-8211

Institute of Slavic Studies, Polish Academy of Sciences, Warsaw

Tatiana Zinowjewa ๑ https://orcid.org/0000-0002-5657-7947

Nicolaus Copernicus University, Toruń

\title{
The Pronunciation of Final Clusters of the Type -tr in Polish*
}

\begin{abstract}
The article reports the commencement of the process of change of the syllable pattern in Polish, consisting in the syllabification of liquid sonorants in some contexts in less sonorous segmental environment (in final clusters with an obstruent in the first position).

A short pilot study was conducted, in which the pronunciation of the word wiatr 'wind' was analysed.
\end{abstract}

\section{Keywords}

syllable pattern, syllabic liquids.

\section{Streszczenie}

Wymowa wygłosowych grup spółgłoskowych typu -tr w języku polskim. Artykuł rejestruje rozpoczęcie procesu zmiany struktury sylabicznej w języku polskim. Zmianę tę zwiastują pojawiające się sylabifikacje sonantów płynnych w niektórych kontekstach, gdzie sonanty występują w mniej sonornym otoczeniu (po obstruencie w wygłosowych grupach spółgłoskowych).

Artykuł przedstawia wyniki krótkiego badania sondażowego, w którym przeanalizowano wymowę wyrazu wiatr.

\section{Słowa kluczowe}

struktura sylaby, sylabiczne sonanty płynne.

* This research did not receive any specific grant from funding agencies in the public, commercial, or not-for-profit sectors. 


\section{Introduction}

Since the emergence of two-peak syllables ${ }^{1}$ in Old Slavic after the loss of the weak jers, the subsequent phonetic development of Slavic languages has been largely determined by the tendency to eliminate such structures. The causes of this tendency are to be sought in universal principles and the process is further accelerated by contact with languages which have one-peak syllables exclusively. Putting aside isolated cases of metathesis in consonant clusters and simplifications of consonant clusters, the principal method of eliminating twopeak syllables is the syllabification of the sonorant, followed by the emergence of the vocalic mini-segment accompanying the syllabic sonorant, and completed with the identification of this vocalic segment with some vowel phoneme from the phonemic inventory of a given language. Each of these stages is represented in present-day Slavic languages.

This path of syllable development is the most expected and most likely in a situation where the basic rhythm of production is disturbed due to vowel reductions. Such a process has occurred in many languages of the world. According to the assumptions of autosegmental phonology as well as metric phonology, syllabification is the lowest basic level of language rhythm. At this level, isochronism seems more consistent than at the higher levels (the rhythm of stress units and the rhythm of intonation units), where the semantics of the text largely determines the length of the units. The appearance of a non-syllabic sound with a relatively high degree of sonority in a less sonorous environment constitutes something of an anomaly, so languages tend to eliminate this irregularity. The elimination may proceed through the reformulation of the consonant group, simplification or, on the contrary, through the strengthening of the sonorant so that it becomes a syllable carrier. Polish had successfully resisted this process for more than 1,000 years, at least in the standard pronunciation. Finally, at the turn of the $21^{\text {st }}$ century, the process of the "levelling" of some syllable slopes was initiated also in Polish.

\section{East Slavic situation}

We observed this process in Russian in the mid-twentieth century. We reported on its phonological consequences in a number of publications (cf. Zinoveva

1 The terms one-peak syllable and two-peak syllable are connected with the so-called sonority theory. In a one-peak syllable, sonority increases towards the centre of the syllable and then it decreases. In a two-peak syllable, additional, non-syllabic sonority peaks appear on the slopes of the syllable. In production, these peaks are typically eliminated or strengthened to the level of the full nucleus. The sonority theory is the most effective and frequently used tool for describing syllabic structures, despite ambiguities connected with the interpretation of this term (Ohala 1992). 
2018). They consist in leading to the contextual neutralisation of the newly created vocalic segment with the phonemes /a/ and /o/. In unstressed positions, both these vowels (morphophonemes) are pronounced as a reduced vowel of a quality approximating the schwa. This will lead to significant changes in the morphophonological structure of Russian, because in such a situation the phoneme /o/ should be posited (represented by [ə]) in words such as memp (metr) [mjetər] 'metre', лump (litr) [Kitər] 'litre', etc. If the written form of the word is unavailable, the identification of the segment of the type [ə], constituting part of the articulation of the vibrant, and [ə] resulting from akanie is full. ${ }^{2}$ The reason for this is the fact that akanie in Russian leads to a strong centralisation of unstressed back vowels.

A similar development took place in Belarusian. As early as in the 60s, Aleksandr Padluzhny postulated the phoneme /a/ in an analogical position in Belarusian words (cf. Kryvicki and Padlužny 1982; Padlužny 1989). This should have led to neutralisation with /a/ in words such as мemp (metr) 'metre' [m'etər] / [m'etar] on the one hand and peдакmap [redaktar] 'editor' on the other. It seems, however, that this neutralisation is still optional. In the Belarusian material collected by Irena Sawicka, [ər] was usually transcribed in the places where / $\mathrm{r}$ / was realised syllabically, whereas in the place of the graphic $a$ in the group -ap in final position [a] was mostly transcribed (Sawicka 2017). The segment [a] is not identified with any vowel phoneme in Belarusian.

\section{Polish situation}

In some Slavic languages, two-peak syllables have been eliminated in all contexts; other Slavic languages have accepted two-peak syllables - permanently, as it seems - at the beginning of words. At present, Polish is the last Slavic language in which two-peak syllables are accepted in initial, medial and final positions in words. It is now the only Slavic language in which liquid consonants in final groups obstruent + liquid sonorant are still pronounced nonsyllabically. What is more, there even occur in Polish similar groups with the final approximant $[w]$, e.g. in careful pronunciation: pomyst [pomisw] 'idea',

${ }^{2}$ Such were the conclusions reached by Tatiana Zinowiewa, who compared the pronunciation of word-final groups with a liquid sonant in words such as Пёtmp (Pëtr) 'Peter' [p ${ }^{j}{ }^{\circ}{ }^{\top} \mathrm{r}$ ] on the one hand and aвmop (avtor) 'author' [aft ${ }^{\ominus} \mathrm{r}$ ] on the other. The author cited a number of erratic forms collected from the Internet, used in Internet slang by younger language users,

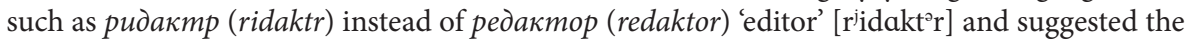
following experiment: listening to a recording of words (pronounced by native speakers of Russian) whose written forms differed only with respect to the presence or absence of a vowel in the middle of the word-final group -тр, e.g. электор (elektor) 'voter' [iKekt ${ }^{\circledR} \mathrm{r}$ ] vs. электр (elektr),

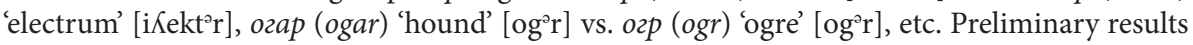
suggest lack of difference in the pronunciation of such pairs of words (Zinoveva 2018). 
pad [padw] (and in other 'undesirable' positions, such as $\nmid k a c$ [wkatc] 'weep', padłszy [padwfi] //patfi] 'fall', past participle). It seems, however, that the syllabification of liquids in the position discussed has begun in Polish, too. This phenomenon is observed in careful speech, in short words, which seems natural. Due to the influence of isochronism, short words are pronounced more slowly, and, thus, with greater precision. The pronunciation of $/ \mathrm{r} /$ approaching syllabic pronunciation can be observed in weather reports and ski-jumping reports, in which the words metr and wiatr are often used.

Up till now, $/ \mathrm{r}$ / in word-final position after a voiceless obstruent and before a pause at the end of an utterance with falling intonation contour has been predominantly devoiced in Polish. Nowadays, as it seems the devoicing is less frequent. The lack of devoicing is the first phase of an incipient change. The next phase is the lengthening of articulation and finally perceptual syllabicity and, potentially, the emergence of a vocalic segment before the sonorant.

The group - $t r$ in the final position in so-called Warsaw pronunciation of older generation is pronounced as follows:

1. as [tr] or [dr] before a voiced obstruent at the beginning of the next word;

2. as [tr] in all other contexts, i.e., in absolute coda, before resonants and before voiceless obstruents in the onset of the next word.

Sandhi in Polish approximates a morphophonological rule, as it obtains almost unexceptionally and is hardly influenced by the changing conditions of production. It happens that even when the conditions change unexpectedly, for instance, the speaker produces an unintended pause, sandhi is realised as if the context remained unchanged (as if the pause did not occur).

The rules for inter-word sandhi in Polish are determined for final obstruents, which (depending on the subsequent context) may become voiced or voiceless. According to the norm of Warsaw pronunciation (the north-east pronunciation, cf. Dukiewicz and Sawicka 1995), a word ending such as in wiatr does not undergo modification in any context because there is a sonorant in the final position. Exceptionally, in the case of the termination of an utterance, accompanied by falling intonation, the whole final fragment of the word (including sonorants and vowels) may become voiceless.

The context examined is, however, exceptional and it happens that the general rule does not obtain in this case. Maria Steffen-Batogowa (1996) examined the pronunciation of such final groups in so-called Cracow-Poznań pronunciation (the south-west pronunciation) ${ }^{3}$ and Tatiana Zinowiewa (1998) carried out a survey for Warsaw pronunciation. The results of this research confirm that analogical contexts are, in principle, pronounced in accordance

${ }^{3}$ The difference between Warsaw pronunciation (the north-east pronunciation) and Cracow-Poznan pronunciation (the south-west pronunciation) consists in the fact that in the former the initial resonant (vowel or sonorant) constitutes the devoicing context for the final obstruent of the preceding word whereas in the latter, this context is the voicing context. 
with the norm irrespective of the speed of delivery and other conditions of production. However, deviations do occur in which sandhi seems more sensitive to the actual phonetic context and strict rules are not observed. In such cases, in contexts such as wiatr wzmaga się 'wind is rising', biuro kadr pracowniczych 'human resources office, voicing and devoicing of obstruents occur irrespective of the sonorant that separates the obstruents: [vjjadr vzmagace] and [bjuro katr pratsovnitfix].

The speech of the language users from a younger generation is characterised by the pronunciation informed by the orthographic form, which results in withdrawing certain assimilations (see, for example, Madejowa 1981; Osowicka 2001; Serowik 2002; Kamińska 2005), reconstructing gemination (Serowik 2000), and in careful realisation of the sonorant in the groups under discussion. The sonorant / $\mathrm{r} /$ in final groups /-tr/ remains voiced in the positions in which it should normally become voiceless (see below). In the next phase, in the case of some speakers, it becomes syllabic. This change is observed only in the case of liquids and occurs mostly in short words, which is expected, because short words are pronounced more slowly than longer ones, ergo, more carefully. Careful pronunciation is identified, in general opinion, with faithfulness to the orthographic form and not to orthoepic principles. For now, the tendency has been observed in the pronunciation of individual speakers, in particular, in the speech of TV presenters and actors, but it is a harbinger of change.

\section{Phonetics of context}

An objective assessment of spectrograms is very difficult, if possible at all. The representations of liquids in spectrograms are very similar to those of vowels. The structure of the Polish rhotic consists of alternating vocalic and consonantal mini-segments. Even in an unquestionably non-syllabic pronunciation, vocalic segments often appear. A number of authors actually define the articulation of the so-called rhotic tap as a segment which is accompanied on both sides by short, centrally articulated vocalic segments of the type: [ə] or [i] (cf. Schmeiser 2009; Savu 2011; Stolarski 2011; Spreafico and Vietti 2013; Jaworski 2018; and others).

A more objective indicator, although also imperfect, would be the duration of the whole segment and its vocalic components. Aural assessment is the only method which makes it possible to assess the functional value of a speech sound as syllabic or not. Not everybody is competent to carry out such assessment; for instance, an average Serb or Czech will always hear syllabicity in the context discussed because they assume that another pronunciation is impossible - their reception is influenced by the specificity of their own language. 
As for the fact that significant differences exist in the pronunciation of similar contexts between Slavic languages, it is indisputable. We may, thus, rely on the aural assessment of the persons who are aware of the differences, in this case, ours. Our competence is based on the knowledge of several Slavic languages in which analogical contexts are pronounced differently. Besides, there occur in our material cases which are unclear, ambivalent, of which it is hard to decide whether their pronunciation is syllabic or not, both on the basis of aural assessment and in the assessment based on spectrograms of a given speech sound. Thus, it may be assumed that this is a gradable phenomenon.

For comparison, we offer a number of spectrograms which present syllabic and non-syllabic pronunciations of sonorants in various languages. Both in the realisations treated as syllabic and in those treated as non-syllabic, there emerge vocalic mini-segments.

\subsection{Non-syllabic realisations}

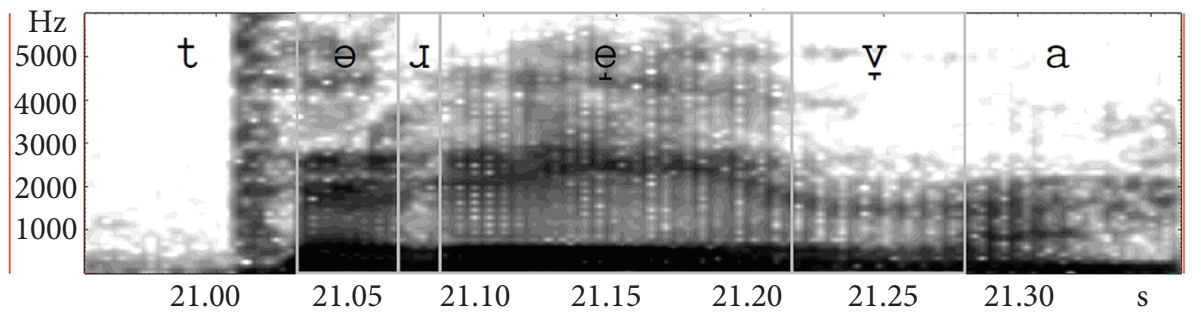

Figure 1. Spectrogram of the Macedonian word mpeбa (treba) 'need' [treba]. ${ }^{4}$ Non-syllabic realisation. Vocalic segments occur on both sides of the single closure

${ }^{4}$ All spectrograms have been made by Agata Trawińska with the use of PRAAT, and the spectrograms in figures 2, 12, 13 with the use of the software Stx of the Austrian Academy of Sciences www.kfs.oeaw.ac.at. Most of them were made for the publication in (Sawicka and Dargiel 2018) and for the purpose of the description of the phonetics and phonology of Macedonian (research funded by a grant from the National Science Centre of Poland, project No 2017/25/B/ HS2/00760, to be published). Spectrograms in figures 14, 15 and 16 have been made by Tatiana Zinowiewa. 


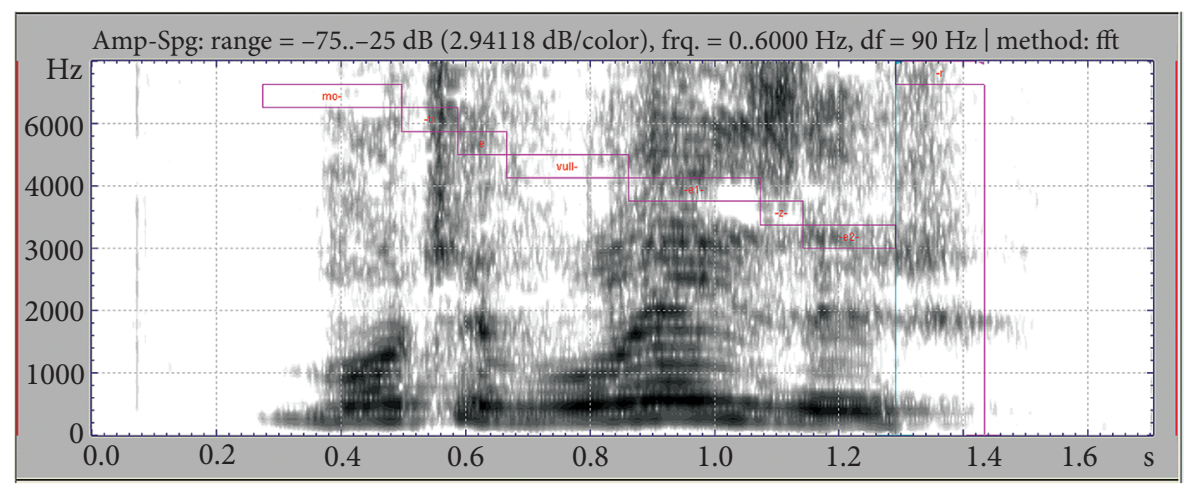

Figure 2. Spectrogram of the expression: motr e vullezër 'sister and brothers' in the Arbëresh dialect (Standard Albanian motër e vullezër [motər e vułezər])

The final [-tr] in motr is not only devoiced, but it also looks and sounds as [tt'] (Sawicka and Dargiel 2018).

\subsection{Syllabic realisations}

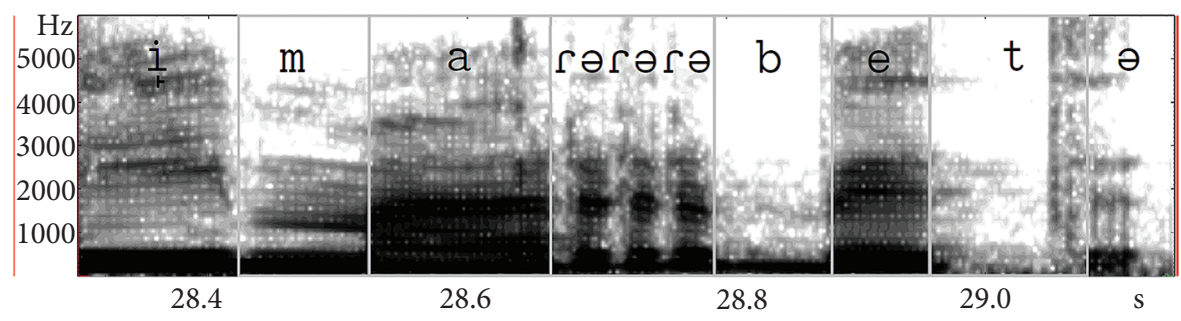

Figure 3. Spectrogram of the Macedonian expression (uмa) 'pбem (ima rbet) [ima ${ }^{\curvearrowright} \mathrm{rbet}$ ] '(has) a spine'

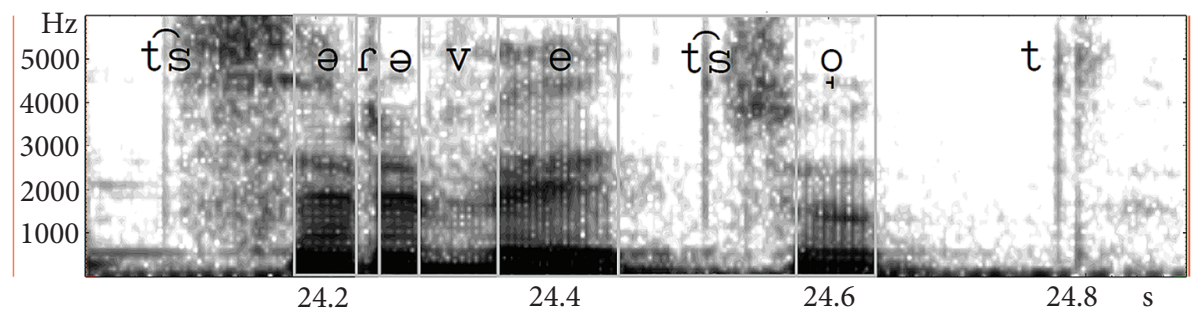

Figure 4. Spectrogram of the Macedonian word ирвецот (crvecot) [t²rvetsot]/ [trrvetsot] 'maggot' 
Let us also compare the Polish non-syllabic pronunciation of the liquid sonorant with the syllabic pronunciation of the sonorant in the same context in Serbian and Macedonian.

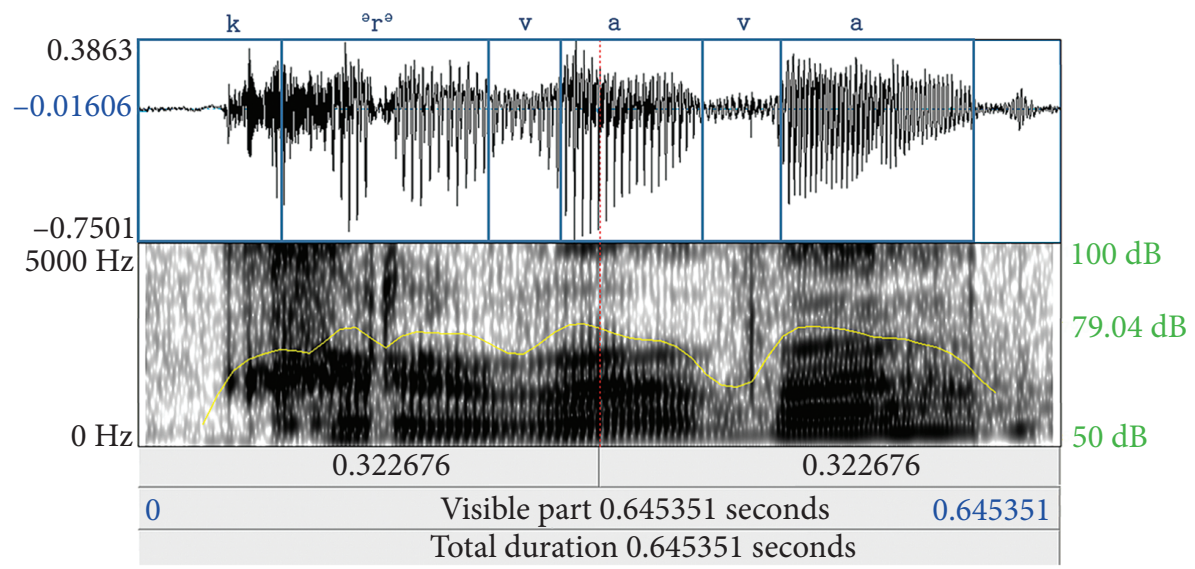

Figure 5. Oscillogram and spectrogram of the Macedonian word крвава (krvava) [krvava]/ [krvava] 'bloody' pronounced in isolation (syllabic $/ \mathrm{r} /$ )

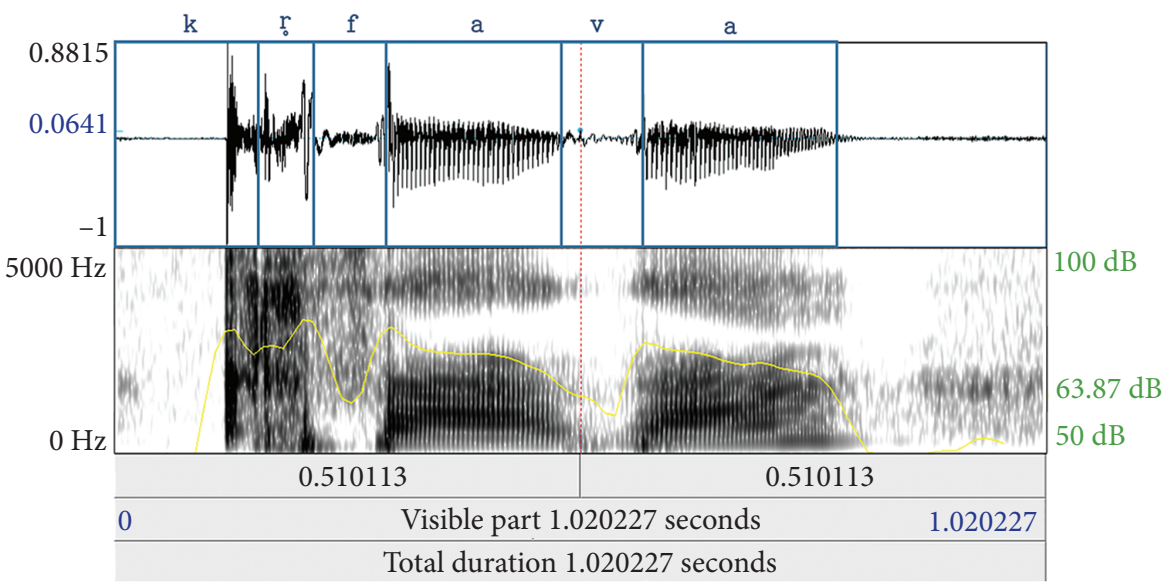

Figure 6. Oscillogram and spectrogram of the Polish word krwawa [krfava] 'bloody' pronounced in isolation (non-syllabic/r/) 
The realisations of the lateral sonorant differ in a similar way: the voiced, 'full' realisation vs. the realisation which is 'deformed', voiceless:

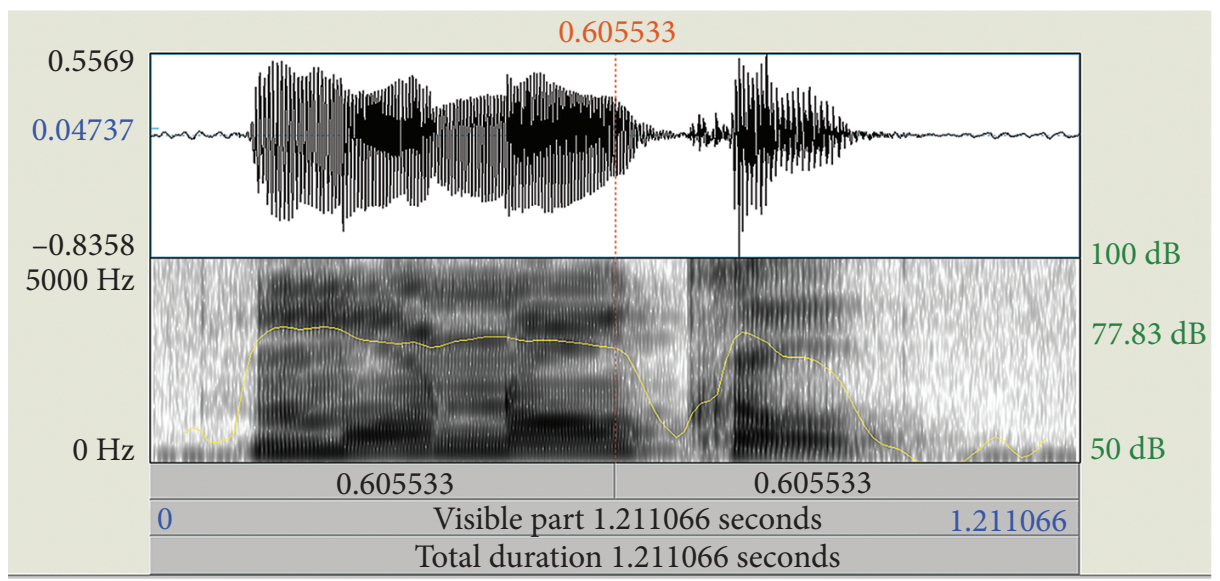

Figure 7. Oscillogram and spectrogram of the Macedonian word монокл (monokl) [monokł] 'monocle' pronounced in isolation (syllabic/1/)

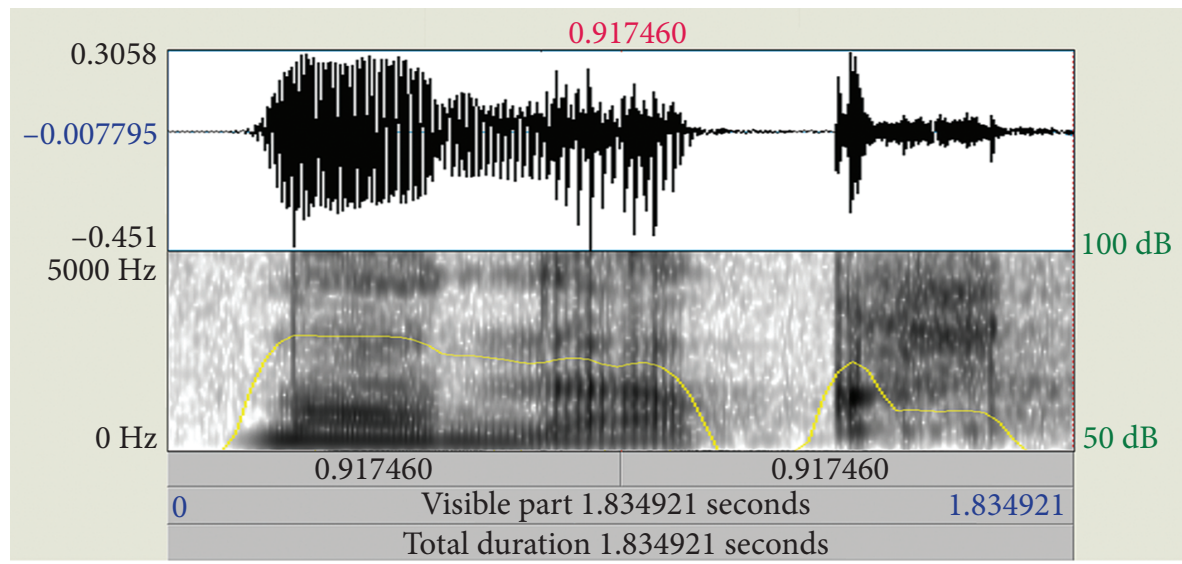

Figure 8. Oscillogram and spectrogram of the Polish word monokl (monokl) [monəkl] 'monocle' pronounced in isolation (non-syllabic/l/) 


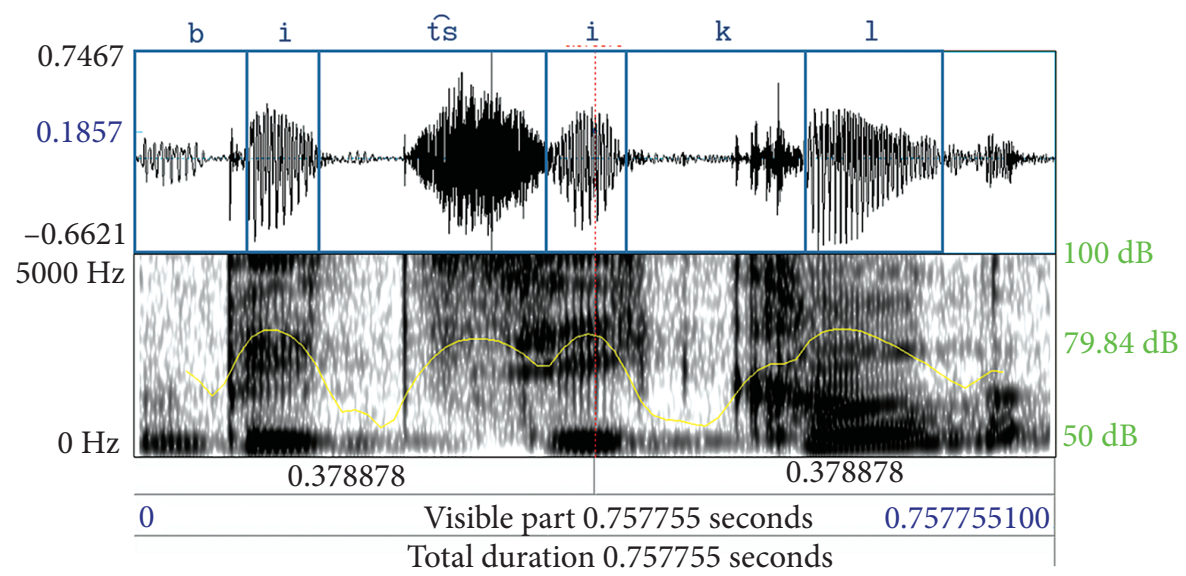

Figure 9. Oscillogram and spectrogram of the Serbian word bicikl [bitsikl] 'bicycle' pronounced in isolation (syllabic /l/)

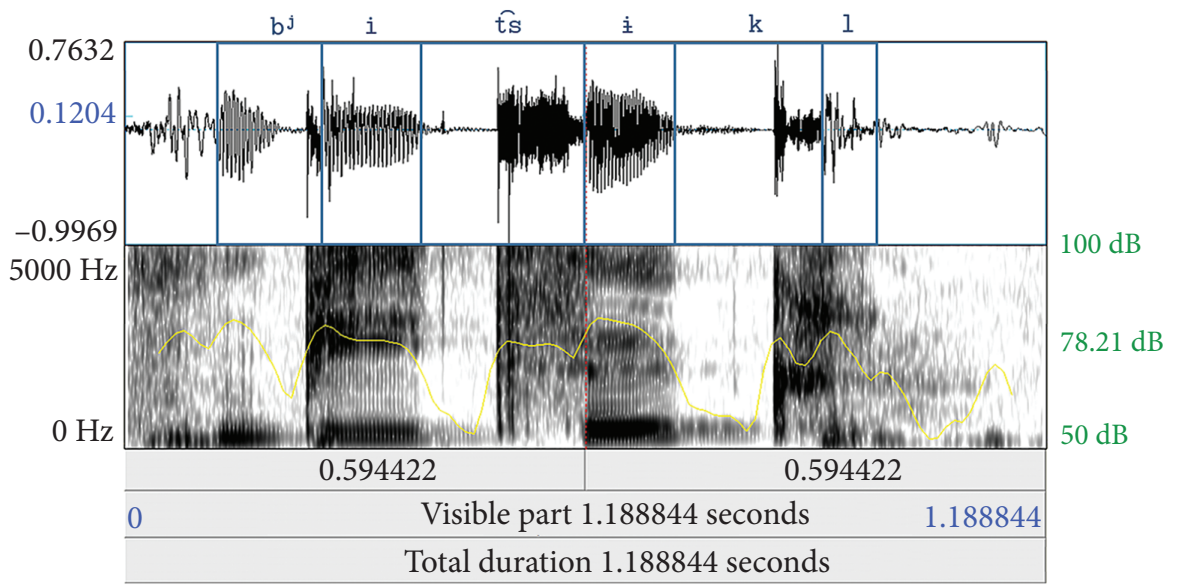

Figure 10. Oscillogram and spectrogram of the Polish word bicykl [bitsikl] 'bicycle' pronounced in isolation (non-syllabic /l/)

Serbian and Macedonian articulations of syllabic sonorants are voiced, last longer and have more vocalic mini-segments than Polish articulations of the sonorants in the same contexts. In favourable conditions, Polish sonorants lose voicing and their structure becomes unclear. This is a typical Polish pronunciation of the contexts discussed.

Macedonian syllabic articulations of / $\mathrm{r} /$ differ from Serbian syllabic articulations. In Macedonian, the vocalic segment before the vibrant is clearly perceivable; in Serbian, a stronger realisation of the consonant can be heard and 
the vocalic segment is rarely heard. This does not influence the phonological classification of this phone in any of these languages. Both in Macedonian and in Serbian it is a combinatory variant of the phoneme $/ r /$. The situation is different in Russian, where the evolved segment [ə] identifies with other vowels pronounced in an unstressed position, which determines its classification as a vowel phoneme rather than a consonantal phoneme.

\section{Survey}

Articulations of / $\mathrm{r} /$ in Polish are discussed in detail in Łobacz (2000). The most typical articulation in the position discussed is shown in figure 11.

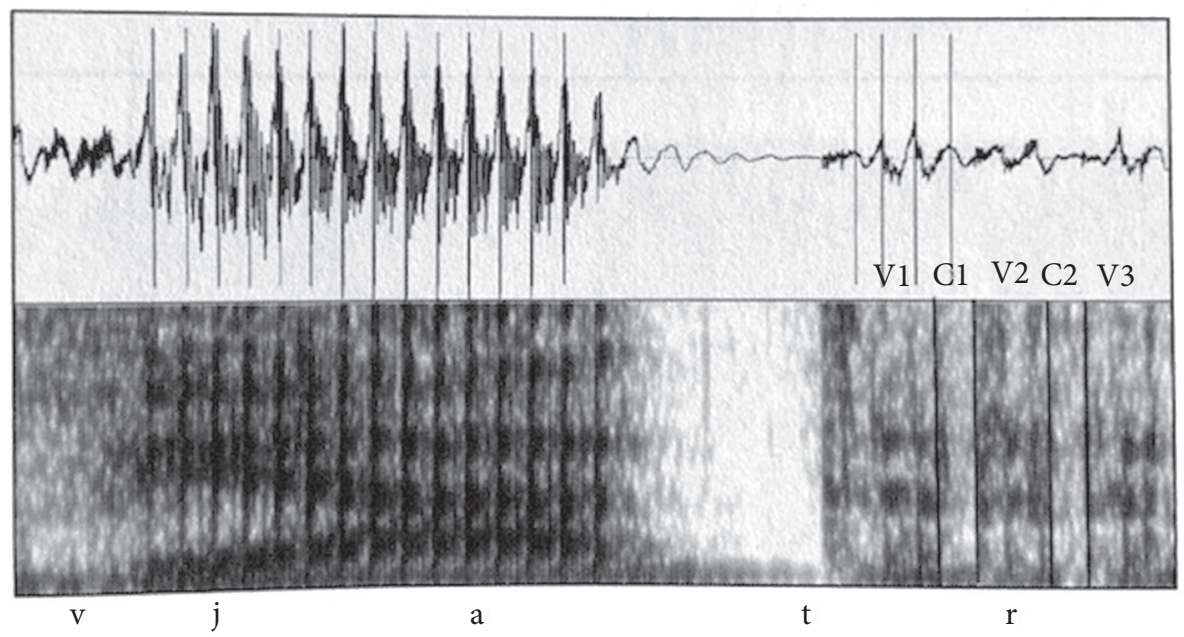

Figure 11. Partially voiceless final /r/ in the Polish word wiatr 'wind'

Source: based on Jaworski 2018.

The occlusive components $\mathrm{C} 1$ and $\mathrm{C} 2$ of the voiceless vibrant shown in figure 11 last $13 \mathrm{~ms}$ and $12 \mathrm{~ms}$ respectively. The vocalic elements which occur between them last $25 \mathrm{~ms}$. This pronunciation is considered as non-syllabic by the author.

In recent years, instances of syllabic pronunciation have appeared in this position. They are not common yet.

In the survey, we analysed the pronunciation of the words wiatr 'wind' and metr 'metre' by one of the most popular Polish weather presenters of the Polish channel TV2, whose pronunciation is characterised by the novelty under examination; also analysed were two potentially syllabic samples excerpted from ski-jumping reports. 


\subsection{Samples excerpted from ski-jumping reports}

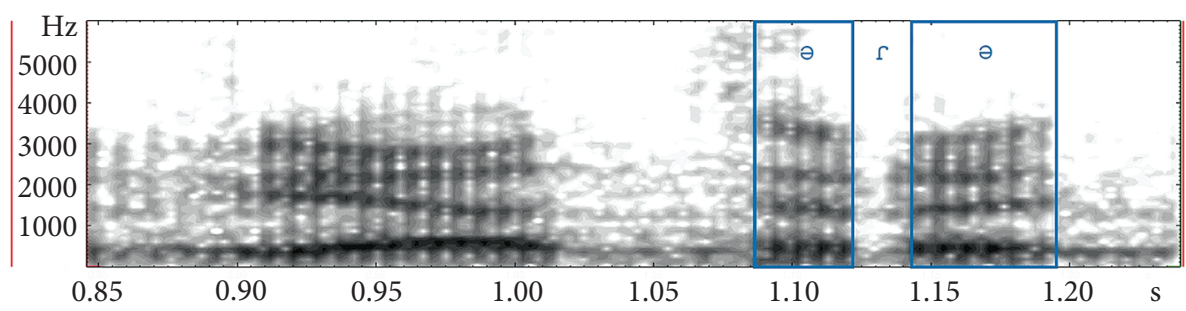

Figure 12. Spectrogram of the word wiatr in the combination of words bonifikata za wiatr \# nie... [boniflikata zav'jatr \# ne] 'reduction for the wind \# is not...'

Two vocalic segments emerged in the structure of $/ \mathrm{r} /$ : the duration of the first schwa amounts to $35,4 \mathrm{~ms}$; the duration of the second schwa is $51,2 \mathrm{~ms}$., thus, longer than in figure 11. For comparison, the duration of the vowel $[a]$ in the preposition $z a$ amounts to $67,1 \mathrm{~ms}$.

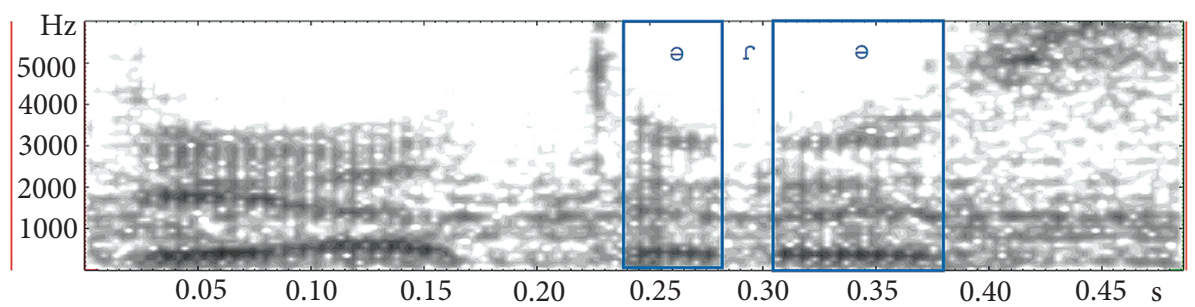

Figure 13. Spectrogram of the word wiatr in the combination of words ...wiatr $z$ tytu [vatr stiwu] '...wind from behind...'

The duration of the first schwa amounts to $41,0 \mathrm{~ms}$; the duration of the second schwa is $72,1 \mathrm{~ms}$. The duration of the vowel [i] in the word "tyłu" amounts to $66,9 \mathrm{~ms}$, which means that in this case the second schwa is even longer than a similar ${ }^{5}$ full vowel in a stressed position.

\subsection{Weather reports}

The word wiatr in the weather reports analysed was pronounced in different ways, irrespective of the beginning of the next word.

${ }^{5}$ The Polish vowel $y$, traditionally transcribed as [i] is, in fact, closer to the pronunciation [ə]. The most appropriate transcription seems [I]. 
Seventy uses of the word wiatr have been excerpted from weather reports. On the basis of aural assessment, their pronunciation was assessed as discussed below.

5.2.1. In 14 samples, wiatr occurred in contexts favouring the preservation of voicing, i.e., before a voiced obstruent in the onset of the next word (e.g. ...wiatr znowu... '... wind again...', wiatr bo... 'wind because..., wiatr w górach... 'wind in the mountains..., ...wiatr da sie we znaki... '...wind will take its toll...', ...wiatr zwłaszcza... '... wind especially..., wiatr będzie... 'wind will be..., etc.).

In this position [r] was always pronounced as voiced and in 6 samples it was unequivocally non-syllabic; in 8 samples it was longer and sounded syllabic.

On the basis of aural perception, we assess that in 8 samples from this group the pronunciation could be considered as syllabic, which amounts to more than $50 \%$ of the samples in the context before a voiced obstruent.

In only 4 samples, the pronunciation represented syllabic realisations which were difficult to assess. These were the phrases ...silny wiatr $w$ górach $i$ nad morzem... '...strong wind in the mountains and on the sea...' and ...przez wiatr znowu... '... because of the wind again..., repeated twice each.

5.2.2. In 56 samples, the words wiatr and metr occurred in contexts favouring devoicing: before a pause, before an voiceless obstruent or a resonorant (vowel or sonorant), e.g. ...na metr kwadratowy... '... per square metre...', ...porywisty wiatr 'gusty wind', etc. However, /r/ underwent devoicing in only 6 samples. Earlier, the pronunciation of a sonorant standing after a voiceless obstruent and before voiceless obstruents or in absolute coda was generally voiceless.

In the remaining 50 samples, the voiced pronunciation of the rhotic was maintained, which is a novel phenomenon.

In 8 samples, we identified the pronunciation of $/ \mathrm{r} /$ as close to syllabic. In all these samples, the group /-tr/ occurred before a pause, but the intonation did not indicate terminated utterances, but incomplete, non-terminated utterances. Pauses occurred as a result of the need to inhale and the lack of final falling intonation and a more careful pronunciation of the coda in such phrases suggest continuation. Such a pronunciation constituted ca. $6,5 \%$ of all utterances with this segmental context.

\subsection{Analysis}

In total, the number of lengthened or potentially syllabic pronunciations in this short survey amounted to ca. $23 \%$. What is more, characteristic is the lack of voicing of / $\mathrm{t} /$ in the group - $t r$ before voiced obstruents in initial positions. The pronunciation of the final group $t r$ as [dr] sometimes occurs (has occurred until now?) in Polish in the position before an initial voiced obstruent of the 
next word. The voicing would constitute unequivocal evidence that the sonorant is not syllabic. Syllabicity, ergo nucleus, separates obstruents and the context favouring assimilation disappears. Previous research (Rubach 1996; Steffen-Batogowa 1996) indicated that inter-word voicing and devoicing of obstruents irrespective of the sonorant that separates them occurred in only $10 \%$ of pronunciations (e.g. wiatr wieje 'wind is blowing' [v'jadr vijeje]). In the pronunciation of the weather presenter, the voicing of the obstruent before the final $/ \mathrm{r} /$ was not observed. Three types of pronunciation of $/ \mathrm{r} /$ were observed in our survey: voiceless non-syllabic (figure 14), voiced non-syllabic (figure $15)$ and voiced (almost) syllabic (figure 16). The samples came from the recordings of TV programmes and are noisy, however, the differences are clearly visible in the oscillograms.

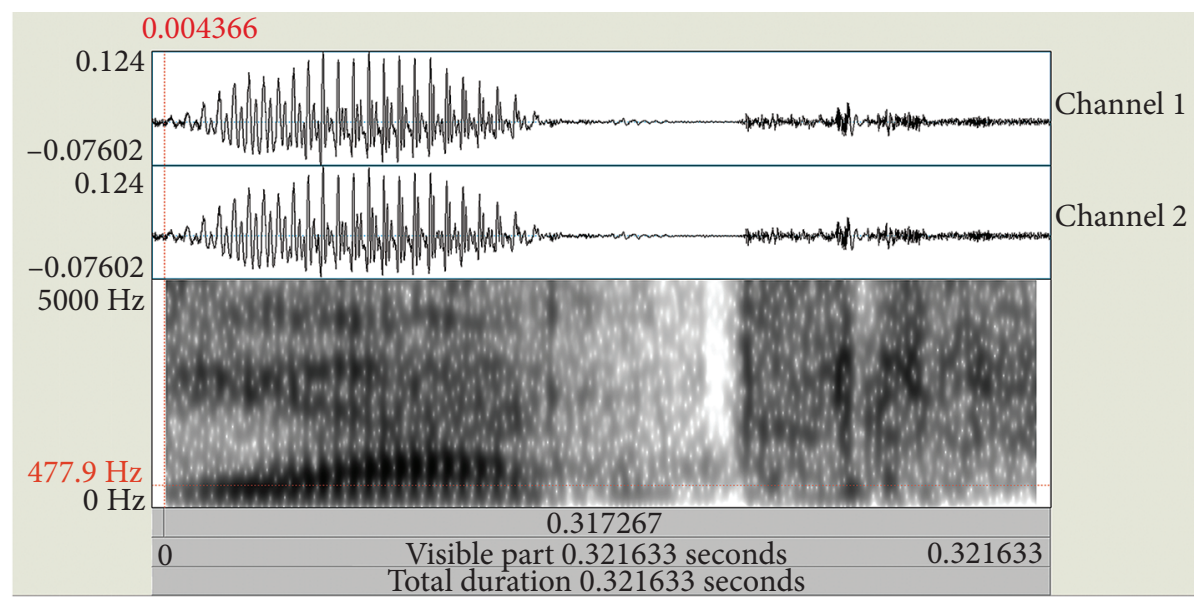

Figure 14. Voiceless pronunciation of $/ \mathrm{r} /$ in the word wiatr 


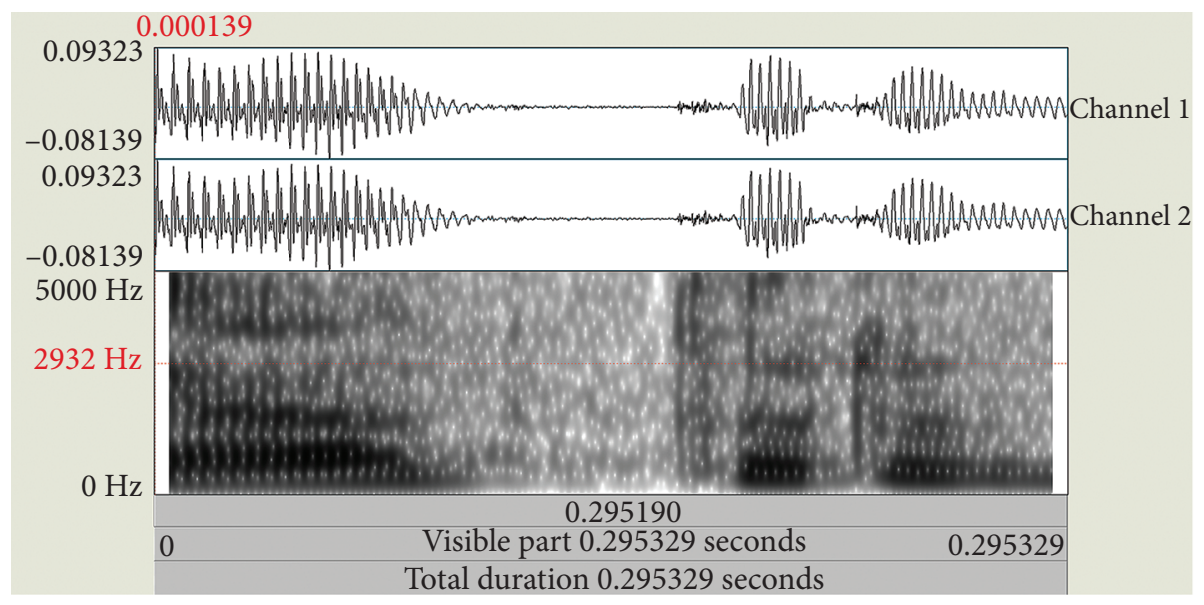

Figure 15. Voiced pronunciation of $/ \mathrm{r} /$ in the word wiatr

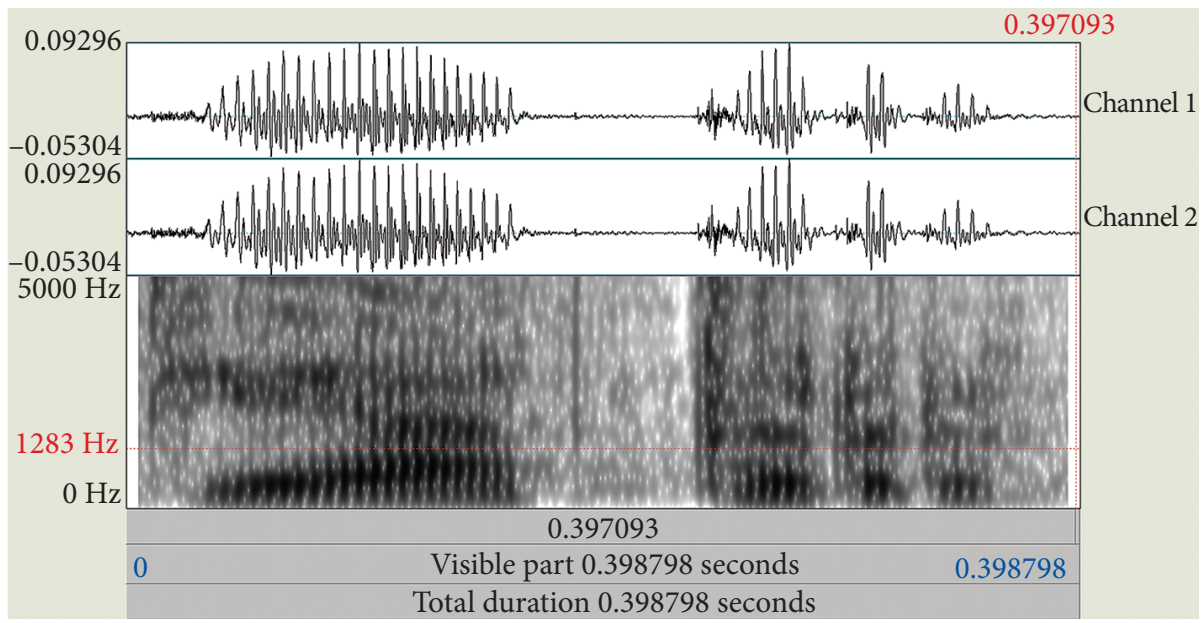

Figure 16. Voiced quasi-syllabic pronunciation of $/ \mathrm{r} /$ in the word wiatr

The syllabic pronunciation is clearly longer (one more occlusion) than the non-syllabic pronunciation.

\section{Conclusion}

Comparing typical Polish non-syllabic realisations in the position under examination with the still less frequent pronunciations for which we postulate syllabicity, we conclude that the process of syllabification, ergo, elimination of 
two-peak syllables in Polish has begun. Thus, we predict that Polish will soon join the group of those Slavic languages which, like Russian or Czech, accept two-peak syllables in the word-initial position, i.e., that initial sonorants occurring before an obstruent are pronounced non-syllabically, e.g. in $t z a$ [wza] 'a tear', rwać [rvate] 'to tear'. In word-final positions, additional non-syllabic sonority peaks will probably be accepted in the form of nasal sonorants. In the remaining final groups, consisting of an obstruent and sonorant, the additional peak will be strengthened and an additional one-peak syllable will be created. The glide $/ \mathrm{j} /$ does not occur at all in word-final position after a consonant, in word-initial position before a consonant, and between consonants. There is also the glide /w/, whose non-syllabic occurrence in these positions is specific to Polish. It is, however, pronounced only in careful production and in favourable syntactic and intonation positions. In regular pronunciation, it simply disappears, e.g., niósł 'carried' [nusw], typically [nus]; similarly, between consonants jabłko 'apple' [jabłko] beside the regular [japko]. An exception is constituted by the word-initial position before a consonant, as in $\nmid z a$ 'tear', $\dashv k a c ́$ 'weep', where the pronunciation [wza], [wkat6] is obligatory.

At present, given the still modest representation of the process discussed in Polish, a more detailed research seems unfounded (for instance, an examination of the length of the vocalic segments which constitute a fragment of the production of $/ \mathrm{r} /$ in the positions under examination). The duration of the vocalic segments was examined only in a few examples; a sampling of modest material from Belarusian was carried out, too, and the results were not unequivocal (Sawicka 2017). A likely cause of this is a high variability in the duration, connected with the syntactic position and, especially, with the position in the intonation contour.

Generally, a broader statistical analysis does not seem justified yet because syllabification is at present a rare feature of individual speakers.

The changes discussed in Polish will lead to distributional changes - new combinatory allophones of sonorants will be created, however, in contrast to Russian or Belarusian, this will not necessitate a reflection on a potential reformulation of the morphophonological shape of words. Schwa should be treated as a fragment of contextual realisation of the sonorant. However, the emergence of a new syllable may cause disturbance in the rules of word accentuation. The prevalent rule of penultimate stress in stress-bearing words acquires new exceptions. Words such as 'orkiestr 'orchestry gen.pl.' or cent 'ymetr 'centimetre' gain an additional syllable and stress remains on the same syllable - the word has a form with stress on the antepenultimate syllable 'orkie-str ['orcest $\left.{ }^{\circledR} \mathrm{r}\right] /$ ['orcestr], cen-t'y-me-tr [tsentimetr]]/ [sentimet $\left.{ }^{2} \mathrm{r}\right]$. The Stress Rule (penultimate stress) still treats $[\mathrm{r}]$ as nonsyllabic. However, the stress facts cannot be taken to constitute evidence that the emerging Syllabic Consonant Rule has not entered phonology yet, because it is difficult to predict whether 
the discussed effect will be permanent or whether stress placement will be adjusted to the general rule or not. In a more distant future, the Russian scenario seems quite likely. ${ }^{6}$ It seems that in Polish there is no independent segment of the schwa type, with an independent phonological qualification; it is not a regular variant of any other vowel either. There is, however, in Polish a centralised vowel $y$ [i] (or rather [I]), so theoretically the pronunciation of wiatr as $\left[v^{j} j a t r r\right]^{7}$ may appear in the future. It is doubtful, however, that this segment will be identified with the phoneme / $\mathrm{i} /$ in the awareness of Polish speakers. The orthographic form is an obstacle. The identification of a unit is based on the knowledge of the orthographic shape and morphophonology, which means that the knowledge of allomorphs also plays an important role in the process.

\section{References}

Dukiewicz Leokadia, SAwicka Irena (1995). Gramatyka wspótczesnego języka polskiego 3. Fonetyka i fonologia. Kraków: Wydawnictwo Instytutu Języka Polskiego PAN.

JawOrski Sylwester (2018). Rhotic Sounds in the Slavic Languages. An Acoustic Study. Hamburg: Verlag Dr. Kovač.

KamiŃsKa Małgorzata (2005). Upodobnienia obstruentów przed dziąsłowymi obstruentami. Toruń: Nicolaus Copernicus University, MA thesis.

KryviCKI Aljaksandar, PADlužNY Aljaksandar (1982). Fanetyka belaruskaj movy. Minsk: Vyšejšaja škola.

Łoвacz Piotra (2000). The Polish rhotic. A preliminary study in acoustic variability and invariance. Speech and Language Technology 4, 85-101.

Madejowa Maria (1981). Tendencje wymawianiowe we współczesnej polszczyźnie literackiej. Studia Polonistyczne, 9, 91-95.

OHALA John (1992). Alternatives to the sonority hierarchy for explaining segmental sequential constraints. Papers from the Parasession on the Syllable, 319-338. Chicago: Chicago Linguistic Society.

Osowicka Magdalena (2001). Palatalność asymilacyjna w języku polskim - konteksty przed spółgłoską. Toruń: Nicolaus Copernicus University, PhD dissertation.

PADLUŽNY Aljaksandar (1989). Fanetyka belaruskaj litaraturnaj movy. Minsk: Vyšejšaja škola.

Rubach Jerzy (1996). Nonsyllabic analysis of voice assimilation in Polish. Linguistic Inquiry 27, 69-110.

${ }^{6}$ A point of interest is whether post-obstruent nasals such as the $[\mathrm{m}]$ in mechanizm 'mechanism' will become syllabic. Their syllabicity would be consistent with the fact that they are almost always voiced. However, based on the Russian scenario, we believe that nasals will remain non-syllabic. Syllabic nasals occur sometimes in Polish only in foreign names such as Clinton, in received pronunciation.

7 This is how Polish students of Slavic studies pronounce the syllabic $r$ in Serbian or Macedonian, e.g. Serb. krk 'neck' [krrk] instead of [krk]. 
SAvu Carmen-Florina (2011). Another Look at the Structure of the Rhotic Tap: Constricted Intervals and Vocalic Elements. Paper presented at the 'r-atics-3 workshop. Free University of Bozen-Bolzano. Italy, December, 2-3.

SAWICKA Irena (2017). Inne spojrzenie na system fonologiczny języka białoruskiego. In Radosław Kaleta (ed.), Białoruś w dyskursie naukowym, 96-203. Warszawa: Katedra Białorutenistyki Uniwersytetu Warszawskiego.

SAwicka Irena, Dargiel Karolina (2018). Struktura e rrokjes shqipe. Prishtina: Akademia e shkencave dhe e arteve.

SCHMEISER Benjamin (2009). An acoustic analysis of intrusive vowels in Guatemalan Spanish /rC/ clusters. University of Pennsylvania Working Papers in Linguistics 15, 191-202.

SERowik Agnieszka (2000). Sposób realizacji geminat w polszczyźnie. Acta Universitatis Nicolai Copernici, Studia Slavica IV, 169-179.

SERowik Agnieszka (2002). Palatalność asymilacyjna w języku polskim - konteksty przed wysokimi wokoidami. Toruń: Nicolaus Copernicus University, PhD dissertation.

Spreafico Lorenzo, Vietti Alessandro (eds.) (2013). Rhotics. New Data and Perspectives. Bolzano: Bozen-Bolzano University Press.

Steffen-Batogowa Maria (1996). On the pronunciation of some Polish consonant clusters containing sonorants. Studia Phonetica Posnaniensia 5, 61-85.

StolARsKi Łukasz (2011). Vocalic Elements in the Articulation of the Polish and English $/ r /$. Paper presented at the conference Languages in Contact. Wrocław, June, 11-12.

Zinoveva Tat'jana (2018). Ešče raz o final'nykh klasterach s sonantami. Linguistica Copernicana 15, 278-289.

Zinowiewa Tatiana (1998). Zagadnienia sandhi $w$ języku rosyjskim $w$ porównaniu z polskim. Toruń: Nicolaus Copernicus University, PhD dissertation.

Irena Sawicka

Instytut Slawistyki Polskiej Akademii Nauk

ul. Juliana Bartoszewicza 1B/17

00-337 Warszawa

irsawicka(at)gmail.com

Tatiana Zinowjewa

Uniwersytet Mikołaja Kopernika w Toruniu

Wydział Filologiczny

Katedra Języków Słowiańskich

ul. Fosa Staromiejska 3

81-100 Toruń

tat_zin(at)umk.pl 